\title{
Ultrasound image measurements of erector spinae muscle thickness at four spinal levels in adolescents with idiopathic scoliosis: reliability and concave-convex comparison
}

\author{
Alan Richter*, Eric C Parent, Gregory Kawchuk, Marc Moreau, Douglas Hedden, Edmond Lou
}

From 10th International Conference on Conservative Management of Spinal Deformities - SOSORT 2013

Annual Meeting

Chicago, IL, USA. 8-11 May 2013

\section{Background}

Muscular characteristics in scoliosis are insufficiently documented. Ultrasound imaging measurements of extensor muscle thickness are commonly used in low back pain (LBP)[1] but not in scoliosis. Taking measurements of extensor muscle thickness may aid in exercise prescription for patients with adolescent idiopathic scoliosis (AIS)[2].

\section{Purpose}

The purpose of this study is to (1) determine the intrarater reliability of erector spinae ultrasound thickness measurements at different spinal levels, and (2) determine the concave-convex differences in erector spinae thickness in patients with AIS.

\section{Methods}

Nine patients with AIS ( 8 females) with a single thoracic curve, aged $13.5 \pm 1.8$ years old, with mean Cobb angles of 39.4 \pm 9.10 , under observation or undergoing brace treatment were included. In a prone position, three ultrasound images of erector thickness were obtained on each side at L3, the upper end vertebra, lower-end vertebra and the apex of the curve in random order. A $5 \mathrm{~cm}$ curvilinear probe was used to capture images of the erectors parasagittally over the facets. Thickness was measured using ImageJ as the distance from the facet to the first fascia line by an examiner blinded to image location and measurements. Reliability was estimated using Intraclass Correlation Coefficients (ICC2,1 and 2,2) and standard error of measurement (SEM). Differences between sides were determined using paired $\mathrm{t}$-tests at each level.

\section{Results}

The intrarater $\operatorname{ICCs}(2,1)$ for a single measurement varied between 0.75 and 0.99 . The ICCs $(2,2)$ corresponding to the average of the most similar two out of three measurements varied between 0.86 and 0.99 , depending on levels. The corresponding SEM for these average measurements varied between 0.03 and $0.17 \mathrm{~cm}$ (mean 0.09 ), depending on sides and levels with no systematic pattern.

The only statistically significant difference between sides was observed at the upper-end vertebra (concave<convex $0.23 \pm 0.22 \mathrm{~cm}$ ). Mean extensor thickness was $1.75 \pm 0.30 \mathrm{~cm}$ and $1.98 \pm 0.34 \mathrm{~cm}$ at the left and right upper-end vertebra level, respectively. Mean thickness was $2.33 \pm 0.11,2.18 \pm 0.14$, and $2.57 \pm 0.12 \mathrm{~cm}$ at the apex, lower-end vertebra and L3, respectively.

\section{Conclusions and discussion}

Adequate intra-rater reliability for research was obtained by averaging the most similar two of three erector spinae thickness measurements. 3 Reliability was similar at all spinal levels and consistent with results in LBP[1]. By measuring at rest, only one small convex-concave thickness difference was detected.

* Correspondence: arichter@ualberta.ca

University of Alberta, Alberta, Canada

(c) 2013 Richter et al; licensee BioMed Central Ltd. This is an Open Access article distributed under the terms of the Creative Commons 


\section{References}

1. Hebert JJ, Koppenhaver SL, Parent EC, et al: A systematic review of the reliability of rehabilitative ultrasound imaging for the quantitative assessment of the abdominal and lumbar trunk muscles. Spine (Phila Pa 1976.) 2009, 34:E848-E856.

2. Negrini S, Fusco C, Minozzi S, et al: Exercises reduce the progression rate of adolescent idiopathic scoliosis: results of a comprehensive systematic review of the literature. Disabil.Rehabil 2008, 30:772-85.

doi:10.1186/1748-7161-8-S2-036

Cite this article as: Richter et al.: Ultrasound image measurements of erector spinae muscle thickness at four spinal levels in adolescents with idiopathic scoliosis: reliability and concave-convex comparison. Scoliosis 2013 8(Suppl 2):036

\section{Submit your next manuscript to BioMed Central} and take full advantage of:

- Convenient online submission

- Thorough peer review

- No space constraints or color figure charges

- Immediate publication on acceptance

- Inclusion in PubMed, CAS, Scopus and Google Scholar

- Research which is freely available for redistribution

Submit your manuscript at www.biomedcentral.com/submit 